\title{
First record of Neobenedenia "melleni" - like species (Monogenea: Capsalidae) in Goliath grouper Epinephelus itajara in Brazil
}

\author{
Primeiro registro de Neobenedenia tipo “melleni” (Monogenea: Capsalidae) \\ em meros (Epinephelus itajara) no Brasil \\ Francisco da Costa Silva ${ }^{1}$; Jonas Rodrigues Leite ${ }^{2}$; Maurício Hostim-Silva ${ }^{2}$; \\ Anita Rademaker Valença ${ }^{3}$; Eduardo Gomes Sanches ${ }^{1 *}$

\begin{abstract}
${ }^{1}$ Núcleo de Pesquisa e Desenvolvimento do Litoral Norte, Instituto de Pesca, Ubatuba, SP, Brasil
${ }^{2}$ Departamento de Ciências Agrárias e Biológicas - DCAB, Centro Universitário Norte do Espírito Santo - CEUNES, Universidade Federal do Espírito Santo - UFES, São Mateus, ES, Brasil

${ }^{3}$ Departamento de Aquicultura, Universidade Federal de Santa Catarina - UFSC, Florianópolis, SC, Brasil
\end{abstract}

Received September 20, 2013

Accepted January 22, 2014

\begin{abstract}
Neobenedenia melleni (MacCallum, 1927) (Monogenea) is a pathogen widely spread in marine teleost cultures around the world. The present paper recorded this parasite species in the Goliath grouper Epinephelus itajara for the first time Brazil. The use of freshwater bath for parasite control was successful for the Goliath grouper.

Keywords: Mariculture, pathogens, fish ectoparasites, jewfish.

\section{Resumo}

Neobenedenia melleni (MacCallum, 1927) (Monogenea) é um patógeno largamente distribuído em culturas de teleósteos marinhos no mundo. No presente trabalho, esta espécie de parasito é registrada pela primeira vez no Mero Epinephelus itajara, no Brasil. A utilização de um banho de água doce foi eficiente para eliminar os parasitos no Mero.

Palavras-chave: Maricultura, patógenos, ectoparasitos, mero.
\end{abstract}

The Goliath grouper, Epinephelus itajara (Lichtenstein, 1822), is the largest grouper in the Atlantic Ocean, exceeding $2.5 \mathrm{~m}$ in total length and $350 \mathrm{~kg}$ in weight (HEEMSTRA; RANDALL, 1993). It is primarily found in the Atlantic west coast, from Florida to Santa Catarina, and in Africa's west coast, and lives in coral and artificial reefs, rocky shores and mangroves. It feeds on a wide variety of fish and invertebrates, mainly lobster and crabs (SADOVY; EKLUND, 1999). Young Goliath groupers live in shallow bays, holes, below undercut ledges in swift tidal creeks draining from mangrove swamp, rivers and estuaries, while adults live in rocks, reefs and artificial structures near and offshore (BULLOCK et al., 1992).

It has slow growth and reproductive rate in natural environment, and its group spawning behavior makes it particularly vulnerable to overfishing. In Brazil, the population decline, the loss of mangrove

\footnotetext{
*Corresponding author: Eduardo Gomes Sanches

Núcleo de Pesquisa e Desenvolvimento do Litoral Norte, Instituto de Pesca,

Av. Cais do Porto, 2275, CEP 11680-000, Ubatuba, SP, Brasil

e-mail: esanches@pesca.sp.gov.br

Financial support: Programa Petrobras Ambiental e Fundação de Apoio à

Pesquisa do Espírito Santo (FAPES).
}

habitat and the lack of data on this species are unaltered. The regulation enacted from 2002 to 2015 which forbids fishing of Goliath groupers. E. itajara turned this species the first marine fish species to have an individual regulation in Brazilian waters. Globally this species is listed as Critically Endangered by IUCN (PUSACK; GRAHAM, 2009).

The monogenoidea Neobenedenia, from the Capsalidae family, is a marine ectoparasite fish commonly found in aquaculture and aquariums (WHITTINGTON, 2004). Outbreaks of this parasite are a serious problem within the marine fish culture (KOESHARYANI et al., 1999). Neobenedenia melleni (MacCallum, 1927) has been cited by Nagasawa and Cruz-Lacierda (2004) in some grouper species from Southeast Asia. These authors highlighted that this species has a cosmopolitan distribution, low specificity for hosts and its pathogenicity is directly linked to fixation methods and hematophagy feeding, causing severe anemia which could lead to death.

The life cycle of such parasite has been described by BondadReantaso et al. (1995), with emphasis on its fast propagation in marine aquaculture systems. These parasites feed on the host's 
mucus and epithelial cells, leading to changes in fish behavior, because they drag their bodies against the substrate causing injuries and culminating in secondary infections. The study's aim was to document the first occurrence of capsalid monogeneans in Goliah grouper (E. itajara) in Brazil.

Five Goliath grouper specimens, with an average length of $61.2 \pm 8.9 \mathrm{~cm}$ and an average weight of $6,742 \pm 385 \mathrm{~g}$, were collected from a shrimp farm located in the state of Pernambuco, Brazil, around mid September, 2012 (SISBIO license number 33022-2). The fish showed a lack of appetite, skin hemorrhages and corneal opacity. An external analysis enabled the visualization of living flattened helminthes parasites, semitransparent on the head and over the eyes. Some parasites were collected and, subsequently fixed in formalin saline and processed for identification (AMATO et al., 1991). The treatment recommended by Sanches (2008) was used for removing the parasites; it consisted on immersing fish in freshwater for only five minutes. Due to the osmotic shock, the parasites died and detached from the fish, which made it possible to collect them at the bottom of the bath tank. A dark bottom tank facilitated the collection of dead parasites.

A total of 87 parasites $(17.4 \pm 3.2$ parasites for fish $)$ were collected from five treated Goliath grouper. The parasites had a flat shape and elongated body, measuring 3.6-6.1 and 1.9-2.8 mm in length and width, respectively (Figure 1). These parasites were identified as the monogenean Neobenedenia, considering that it lacked vagina and its accessory gland reservoir was contained in the penis sac (WHITTINGTON; HORTON, 1996). Finally, according to the morphological characteristics, it was identified as Neobenedenia "melleni"- like species, in accordance to Whittington (2004), which considers $N$. "melleni” a complex species. Further morphological and molecular analyses of $N$. "melleni" isolates are needed. Other authors described $N$. melleni parasitizing different fishes in Brazil. Sanches and Vianna (2007) in dusky grouper (Epinephelus marginatus) in Ubatuba, state of São Paulo, Carvalho and Luque (2009) in swordfish (Trichiurus lepturus) from the coast of Rio de Janeiro and Kerber et al. (2011) in cobia (Rachycentron canadum) in Ilhabela, state of São Paulo. This is the first record

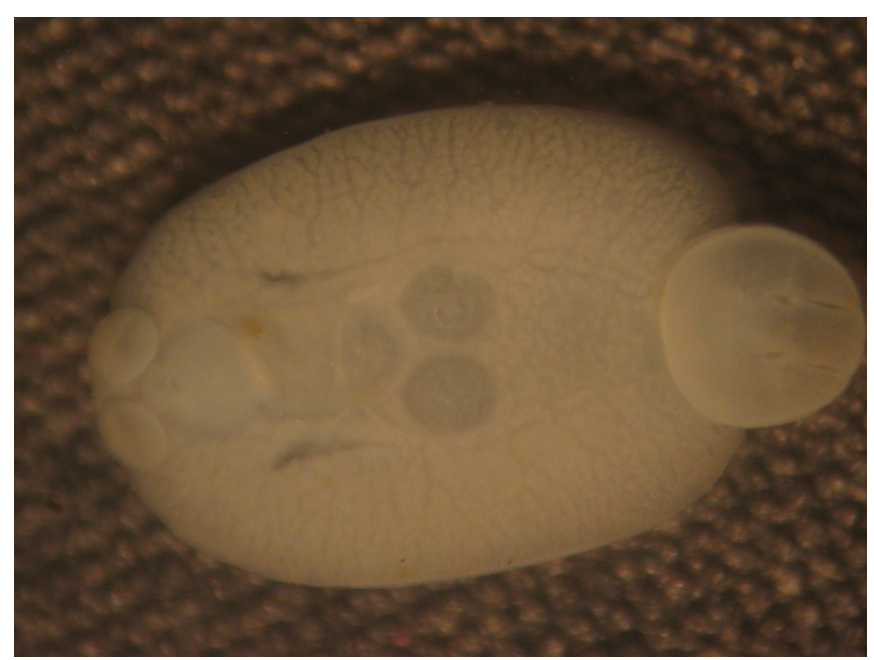

Figure 1. Parasite Neobenedenia melleni collected from a specimen of Epinephelus itajara. of a Neobenedenia "melleni" - like species parasitizing Epinephelus itajara in the world. Specimens of $N$. "melleni"- like species were deposited in the Helminthological Collection of Instituto de Biociências de Botucatu, Universidade Estadual Paulista (CHIBB $\left.\mathrm{N}^{\circ} 7063\right)$.

The symptoms found in E. itajara, such as body darkness, erratic swimming, exophthalmia and hemorrhage in different parts of the body were similar to those found in Epinephelus tauvina (Forskal) parasitized by capsalids. This subsequently resulted in secondary bacterial infection (JITHENDRAN et al., 2005). The pathogenic potential of $N$. melleni was described as the dusky grouper Epinephelus marginatus (Lowe) by Sanches and Vianna (2007), and identified an expressive quantity of parasite in dusky grouper causing destruction of the ocular globe, bacterial infections and high mortality.

Water temperature of shrimp ponds (Goliath grouper collect point) was $28^{\circ} \mathrm{C}$ and salinity 35 . Water temperature and salinity favored the reproduction and development of monogeneans (HIRAZAWA et al., 2010). In spite of the low specificity of $N$. melleni, recent studies show that some fish species have higher resistance to this parasite. Ohno et al. (2008) observed that Seriola quinqueradiata (Temminck and Schlegel) and Paralichthys olivaceus (Temminck and Schlegel) were more resistant than Seriola dumerili (Risso) when exposed to $N$. melleni, indicating it is an important characteristic that could help choose the strongest species for aquaculture. Three other species of fish (Mugil liza, Lutjanus cyanopterus and Centropomus undecimalis) were collected in the same place, but they did not host parasites. This may indicate that the Goliath grouper has great sensibility to $N$. melleni in relation to other species.

It was found that freshwater bath during a span of five minutes was effective in dislodging the parasite from the gills and skin of E. itajara. Freshwater baths have been used in successful marine parasite control (Sanches et al., 2007). A detailed research of freshwater bath treatment and other disinfectants using chemicals as well as the host tolerance are needed on a large number of fish.

\section{Acknowledgements}

We thank Petrobras's Programa Petrobras Ambiental for the research funds, Fundação de Apoio a Pesquisa do Espírito Santo (FAPES) for the scholarship, and Meros do Brazil Project.

\section{References}

Amato JFR, Boeger W, Amato SB. Coleta e processamento de parasitos de pescado. Rio de Janeiro: UFRRJ; 1991.

Bondad-Reantaso MG, Ogawa K, Funkudome M, Wakabayashi H. Reproduction and growth of Neobenedenia girellae (Monogenea: Capsalidae), a skin parasite of cultured marine fishes of Japan. Fish Pathol 1995; 30(3): 227-231. http://dx.doi.org/10.3147/jsfp.30.227

Bullock LH, Murphy MD, Godcharles MF, Mitchell ME. Age, growth, and reproduction of jewfish Epinephelus itajara in the eastern Gulf of Mexico. Fish Bul 1992; 90(1): 243-249. 
Carvalho AR, Luque JL. Ocorrência de Neobenedenia melleni (Monogenea; Capsalidae) em Trichiurus lepturus (Perciformes; Trichuridade), naturalmente infestados, no litoral do Rio de Janeiro, Brasil. Rev Bras Parasitol Vet 2009; 18(S1): 74-76. http://dx.doi. org/10.4322/rbpv.018e1015

Heemstra PC, Randall JE. Groupers of the world (Family Serranidae, Subfamily Epinephelinae). Rome: FAO; 1993.

Hirazawa N, Takano R, Hagiwara H, Noguchi M, Narita M. The influence of different water temperatures on Neobenedenia girellae (Monogenea) infection, parasite growth, egg production and emerging second generation on amberjack Seriola dumerili (Carangidae) and the histopathological effect of this parasite on fish skin. Aquaculture 2010; 299(1-4): 2-7. http://dx.doi.org/10.1016/j. aquaculture.2009.11.025

Jithendran KP, Vijayan KK, Alavandi SV, Kailasam M. Benedenia epinepheli (Yamaguti, 1937), a monogenean parasite in captive broodstock of grouper, Epinephelus tauvina (Forskal). Asian Fish Sci 2005; 18(1): 121-126.

Kerber CE, Sanches EG, Santiago M, Luque JL. First record of Neobenedenia melleni (Monogenea: Capsalidae) in sea-farmed cobia (Rachycentron canadum) in Brazil. Rev Bras Parasitol Vet 2011; 20(4): 331 333. http://dx.doi.org/10.1590/S1984-29612011000400013

Koesharyani I, Yuasa K, Hatai K. Two species of Capsalid monogeneans infecting cultured humpback grouper Cromileptes altivelis in Indonesia. Fish Pathol 1999; 34(3): 165-166. http://dx.doi.org/10.3147/jsfp.34.165

Nagasawa K, Cruz-Lacierda ER. Diseases of cultured groupers. Iloilo: Southeast Asian Fisheries Development Center; 2004.

Ohno Y, Kawano F, Hirazawa N. Susceptibility by amberjack (Seriola dumerili), yellowtail (S. quinqueradiata) and Japanese flounder
(Paralichthys olivaceus) to Neobenedenia girellae (Monogenea) infection and their acquired protection. Aquaculture 2008; 274(1): 30-35. http:// dx.doi.org/10.1016/j.aquaculture.2007.11.013

Pusack TJ, Graham RT. Threatened fishes of the world: Epinephelus itajara (Lichtenstein, 1822) (Epinephelidae, Serranidae). Environ Biol Fish 2009; 86(2): 293-294. http://dx.doi.org/10.1007/s10641-0099509-0

Sadovy Y, Eklund YAM. Synopsis of biological data on the nassau grouper, Ephinephelus striatus (Bloch, 1792) and the jewfish, E. itajara (Lichtenstein, 1822). Rome: FAO; 1999.

Sanches EG, Vianna RT. Ocorrência de Neobenedenia melleni (Monogenea: Capsalidae) em garoupa-verdadeira Epinephelus marginatus (Lowe, 1834) cultivada em tanques-rede. Arq Ciên Mar 2007; 40(2): 96 100 .

Sanches EG, Ostini S, Rodrigues VCS. Ocorrência e tratamento de monogenoides em alevinos de pampo (Trachinotus carolinus) cultivados experimentalmente na região norte do estado de São Paulo. Rev Bras Parasitol Vet 2007; 16(1): 1-4.

Sanches EG. Controle de Neobenedenia melleni (MacCallum, 1927) (Monogenea: Capsalidae) em garoupa-verdadeira, Epinephelus marginatus (Lowe, 1834), cultivada em tanques-rede. Rev Bras Parasitol Vet 2008; 17(3): 145-149.

Whittington ID, Horton MA. A revision of Neobenedenia Yamaguti, 1963 (Monogenea: Capsalidae) including a redescription of $N$. melleni (MacCallum, 1927) Yamaguti, 1963. J Nat Hist 1996; 30(8): 1113-1156. http://dx.doi.org/10.1080/00222939600770611

Whittington ID. The Capsalidae (Monogenea: Monopisthocotylea): a review of diversity, classification and phylogeny with a note about species complexes. Folia Parasitol 2004; 51(2-3):109-122. 